\title{
Extracellular Enzyme Activity Beneath Temperate Trees Growing Under Elevated Carbon Dioxide and Ozone
}

\author{
Jennifer L. Larson, Donald R. Zak,* and Robert L. Sinsabaugh
}

\begin{abstract}
Soil microorganisms are limited by the amount and type of plantderived substrates entering soil, and we reasoned that changes in the production and biochemical constituents of plant litter produced under elevated $\mathrm{CO}_{2}$ and $\mathrm{O}_{3}$ would elicit physiological changes in soil microbial communities. To test this idea, we studied microbial activity beneath trembling aspen (Populus tremuloides Michx.), paper birch (Betula papyrifera Marsh.), and sugar maple (Acer saccharum Marsh.) growing under experimental atmospheric $\mathrm{CO}_{2}$ (ambient and $522.7 \mu \mathrm{L}$

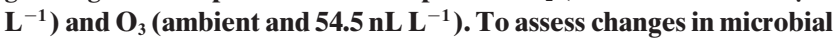
community function, we measured microbial biomass, respiration, and the metabolism of root-derived substrates using BIOLOG GN microplates. We also measured the activity of phosphatase, leucine aminopeptidase, $\alpha$-glucosidase, $\mathbf{N}$-acetylglucosaminidase, cellobiohydrolase, phenol oxidase, and peroxidase enzymes, which are involved in plant and fungal litter decomposition. Microbial biomass and respiration were not significantly altered by elevated $\mathrm{CO}_{2}$ and $\mathrm{O}_{3}$. Cellobiohydrolase activity significantly increased under elevated $\mathrm{CO}_{2}$; however, this response was eliminated by elevated $\mathrm{O}_{3} \cdot \mathrm{N}$-acetylglucosaminidase activity also increased under elevated $\mathrm{CO}_{2}$, but elevated $\mathrm{O}_{3}$ did not significantly alter this response. We found no difference in the metabolism of amino acids, organic acids, and simple carbohydrates, suggesting our experimental treatments did not alter the use of these substrates by soil microorganisms. Our analysis indicates that changes in plant growth in response to elevated $\mathrm{CO}_{2}$ and $\mathrm{O}_{3}$ alters microbial metabolism in soil.
\end{abstract}

$\mathrm{T}$ HE INCREASING CONCENTRATION of atmospheric $\mathrm{CO}_{2}$ has the potential to alter the cycling of $\mathrm{C}$ and $\mathrm{N}$ in terrestrial ecosystems, because it can modify the production and biochemistry of plant litter entering soil, which, in turn, controls microbial activity. Elevated $\mathrm{CO}_{2}$ can increase photosynthesis (Kubiske et al., 1997; Curtis et al., 2000) and plant growth (Mikan et al., 2000; Zak et al., 2000a), as well as alter the biochemical composition of plant tissue produced above (Cotrufo et al., 1994) and belowground (Cotrufo and Ineson, 1995). Roots are an important source of organic substrates for microbial growth, and most studies suggest root production will increase as $\mathrm{CO}_{2}$ accumulates in the Earth's atmosphere (Pregitzer et al., 2000). Moreover, elevated $\mathrm{CO}_{2}$ can increase fine root $\mathrm{C} / \mathrm{N}$ in some species (Betula pendula and Picea sitchensis; Cotrufo and Ineson, 1995) and alter concentrations of starch, sugar, and total nonstructural carbohydrates in others (Pinus taeda; Lewis et al., 1994). Therefore, the degree to which elevated $\mathrm{CO}_{2}$ modifies the production and chemistry of root and leaf litter should have direct effects on soil microorganisms, be-

J.L. Larson and D.R. Zak, School of Natural Resources \& Environment, Univ. of Michigan, Ann Arbor, MI 48109; R.L. Sinsabaugh, Dep. of Earth, Ecological and Environmental Sciences, Univ. of Toledo, Toledo, OH 43606-3390. Received 9 Mar. 2001. *Corresponding author(drzak@umich.edu).

Published in Soil Sci. Soc. Am. J. 66:1848-1856 (2002). cause these plant tissues are the primary substrates for microbial metabolism in soil.

Ozone is a greenhouse gas that is accumulating in the lower atmosphere, and elevated $\mathrm{O}_{3}$ has the potential to alter soil microbial communities through its influence on plant litter production. Elevated $\mathrm{O}_{3}$ can decrease photosynthesis (Pye, 1988; Coleman et al., 1995a) and net C gain (Skärby et al., 1987; Reich et al., 1990) in many woody plants, which should modify litter production. For example, high levels of $\mathrm{O}_{3}$ often decrease root growth to a greater extent than foliage or stem growth (Manning et al., 1971; Blum and Tingey, 1977; Hogsett et al., 1985). Elevated $\mathrm{O}_{3}$ also can modify the biochemical composition of fine roots, wherein starch and soluble sugar concentrations can decline following exposure to elevated $\mathrm{O}_{3}$ (Andersen et al., 1991). It is possible that decreased growth and biochemical changes under elevated $\mathrm{O}_{3}$ could potentially mitigate increases in plant growth and changes in tissue biochemistry resulting from elevated atmospheric $\mathrm{CO}_{2}$. However, we do not understand how these atmospheric gases will interact to alter the input of organic substrates to soil, which could potentially modify microbial activity in soil.

In a recent experiment, we observed that elevated $\mathrm{CO}_{2}$ significantly increased the biomass of living and dead fine roots, but the magnitude $(83-113 \%)$ of this response differed between tree species and was eliminated by elevated $\mathrm{O}_{3}$ (King et al., 2001). Because microbial growth is constrained by the type and amount of organic substrates entering soil (Babiuk and Paul, 1970; Smith and Paul, 1990), the aforementioned changes in belowground plant growth could potentially alter both substrate availability and microbial activity. The presence of substrates can induce the synthesis of specific extracellular enzymes (Paul and Clark, 1996), and we reasoned that the activity of key enzymes involved with plant litter decomposition should respond to changes in fine-root litter under elevated $\mathrm{CO}_{2}$ and $\mathrm{O}_{3}$. We also reasoned that changes in microbial activity under elevated $\mathrm{CO}_{2}$ and $\mathrm{O}_{3}$ would differ among plant taxa. To test these ideas, we measured extracellular enzyme activities and the metabolism of labile, root-derived substrates beneath contrasting temperate tree species grown under experimental $\mathrm{CO}_{2}$ and $\mathrm{O}_{3}$ treatments.

\section{MATERIALS AND METHODS}

\section{Experimental Design}

Our study was conducted at a free-air $\mathrm{CO}_{2}$ and $\mathrm{O}_{3}$ enrichment (FACE) experiment located $25 \mathrm{~km}$ west of Rhinelander,

Abbreviations: FACE, free-air $\mathrm{CO}_{2}$ and $\mathrm{O}_{3}$ enrichment; $\mathrm{MB}_{\mathrm{c}}$, microbial biomass C; MUB, methylumbelliferone; PCA, principal components analysis. 
Table 1. Summary of physical and chemical soil properties beneath plants grown under experimental $\mathrm{CO}_{2}$ and $\mathrm{O}_{3}$ treatments. Soil samples were collected prior to planting within each FACE ring, and treatment means are presented with the standard deviations enclosed in parentheses. Additional detail can be found in Dickson et al. (2000).

\begin{tabular}{|c|c|c|c|c|}
\hline & \multicolumn{2}{|c|}{ Ambient $\mathrm{O}_{3}$} & \multicolumn{2}{|c|}{ Elevated $\mathrm{O}_{3}$} \\
\hline & Ambient $\mathrm{CO}_{2}$ & Elevated $\mathrm{CO}_{2}$ & Ambient $\mathrm{CO}_{2}$ & Elevated $\mathrm{CO}_{2}$ \\
\hline \multicolumn{5}{|l|}{ Soil texture } \\
\hline \% sand & $55.1(3.58)$ & $53.9(2.60)$ & $58.3(1.98)$ & $55.0(2.94)$ \\
\hline$\%$ silt & 36.1 (3.15) & 37.8 (2.30) & 35.3 (3.74) & 37.4 (2.68) \\
\hline$\%$ clay & 8.7 (1.31) & 8.4 (1.04) & $6.4(1.87)$ & 7.7 (0.72) \\
\hline Gravimetric moisture content: $\boldsymbol{\theta}_{(\mathrm{WHC})}$ & $0.10(0.02)$ & $0.11(0.01)$ & $0.10(0.002)$ & $0.11(0.005)$ \\
\hline $\mathbf{D}_{b}, \mathbf{M g ~ m}^{-3 \dagger}$ & 2.37 (0.14) & $1.30(0.13)$ & $1.32(0.15)$ & $1.43(0.10)$ \\
\hline Total C, \% & $1.54(0.27)$ & $1.68(0.33)$ & $1.60(0.32)$ & $1.31(0.20)$ \\
\hline Total N, \% & $0.12(0.02)$ & $0.13(0.03)$ & $0.12(0.03)$ & $0.10(0.0)$ \\
\hline $\mathbf{C} / \mathbf{N}$ & $12.9(0.77)$ & $12.4(0.44)$ & $13.5(0.70)$ & $12.8(0.65)$ \\
\hline Extractable $\mathbf{P}, \mathrm{g} \mathrm{N}^{-1}$ & 124 (28.1) & 155 (23.5) & 132 (22.4) & 136 (17.3) \\
\hline
\end{tabular}

$\dagger$ Bulk density.

WI. This experiment consists of twelve 30-m-diam. FACE rings, assigned to factorial treatments of atmospheric $\mathrm{CO}_{2}$ (ambient and $522.7 \mu \mathrm{L} \mathrm{L}^{-1}$ ) and $\mathrm{O}_{3}$ (ambient and $54.5 \mathrm{~nL} \mathrm{~L}^{-1}$; see Dickson et al., 2000 for details). Treatments were arranged in a complete block design, with three replications of each treatment combination. Each FACE ring was divided into three sections. In one-half of each ring, we planted five trembling aspen genotypes of differing $\mathrm{O}_{3}$ and $\mathrm{CO}_{2}$ responsiveness (Coleman et al., 1995a,b; Curtis et al., 2000). The other half of each ring was further divided into two quarters; one was planted with aspen and sugar maple and the other was planted with aspen and paper birch. In June 1997, trees were planted at a 1 by $1 \mathrm{~m}$ spacing in each ring section, and our sampling occurred during the second full growing season after planting. Mean soil properties for the $\mathrm{CO}_{2}$ and $\mathrm{O}_{3}$ treatment combinations are summarized in Table 1 .

To measure microbial activity and biomass in soil, we collected six 2.5 by $10 \mathrm{~cm}$ soil cores from each section of the twelve FACE rings. Samples were collected at random locations between tree stems. These samples were composited by ring section in the field, stored on ice, and transported to our laboratory for analysis. Fine roots in our samples were removed using forceps, and rhizosphere soil was removed from the roots by shaking them vigorously inside a polyethylene bag. We used nonrhizosphere soil for our analyses of microbial biomass $\mathrm{C}\left(\mathrm{MB}_{\mathrm{c}}\right)$, respiration, and extracellular enzyme activity, and we assayed the metabolism of labile, root-derived substrates using rhizosphere soil. The small amount of rhizosphere soil collected from our cores precluded measurements of $\mathrm{MB}_{\mathrm{c}}$, respiration, and extracellular enzyme activity. Samples were collected in May, July, and October 1999 to quantify seasonal differences in the aforementioned attributes.

\section{Microbial Biomass Carbon and Respiration}

Two 30-g subsamples of nonrhizosphere soil from each ring section were used to determine $\mathrm{MB}_{\mathrm{c}}$ and respiration using the $\mathrm{CHCl}_{3}$ fumigation-incubation technique. One subsample was fumigated for $24 \mathrm{~h}$ with ethanol-free chloroform in a vacuum desiccator, while the second subsample was incubated without chloroform (control). Following the 24-h incubation, the desiccator containing the fumigated samples was evacuated eight times to remove remaining chloroform. Each fumigated sample was inoculated with $0.5 \mathrm{~g}$ of the corresponding control sample. Each fumigated and control sample was sealed in a $1-\mathrm{L}$ mason jar and incubated at $25^{\circ} \mathrm{C}$ for $14 \mathrm{~d}$. Following the 14-d incubation, the headspace gas of the jars was analyzed for $\mathrm{CO}_{2}$ using a Tracor 540 gas chromatograph (Tremetrics Corp., Austin, TX). Microbial biomass was determined by subtracting the amount of $\mathrm{CO}_{2}$ in the control sample from that in the fumigated sample. The difference was divided by a cor- rection factor $\left(K_{\mathrm{c}}=0.41\right)$ to estimate $\mathrm{MB}_{\mathrm{c}}$ (Voroney and Paul, 1984). Microbial respiration was measured as the increase in $\mathrm{CO}_{2}$ in unfumigated samples over the 14-d incubation.

\section{Enzyme Assays}

Soil microorganisms synthesize extracellular enzymes based on the concentration of substrates present in the soil (Paul and Clark, 1996). Therefore, changes in plant-derived substrates entering soil under elevated $\mathrm{CO}_{2}$ and $\mathrm{O}_{3}$ should alter the activity of enzymes used in their degradation. We used methylumbelliferone (MUB) linked substrates to determine the rate at which the microbial community in nonrhizosphere soil metabolized six classes of plant-derived compounds (sensu Sinsabaugh et al., 1999). We assayed the activities of $1,4-\alpha$-glucosidase, cellobiohydrolase, phosphatase, $1,4-\beta-N$-acetylglucosaminidase, and leucine-aminopeptidase.

We suspended $1.0 \mathrm{~g}$ of nonrhizosphere soil from each composite sample in $60 \mathrm{~mL}$ of $50 \mathrm{mM}$ acetate buffer ( $\mathrm{pH} 5.0$ ). The slurry was mixed with a tissue homogenizer (Polytron Devices Inc., Paterson, NJ) and diluted with additional buffer to $125 \mathrm{~mL}$. The suspensions were stored in 125-mL Nalgene screw-cap bottles for up to $30 \mathrm{~min}$ prior to analysis. Sixteen replicates of three separate enzyme assays were conducted on individual 96-well microplates. Each plate also contained eight replicates of a blank, a 4-MUB standard, a negative control, and a quench standard. Plates were incubated at $25^{\circ} \mathrm{C}$ and $25 \mu \mathrm{L}$ of $200 \mathrm{~m} M \mathrm{NaOH}$ was added to each well to terminate the enzymatic reactions. Fluorescence resulting from the cleavage of 4-MUB from utilized substrate was determined with an $f$-Max fluorimeter (Molecular Devices Corp., Sunnyvale, CA). Excitation energy was $355 \mathrm{~nm}$ and emission was measured at $460 \mathrm{~nm}$. Enzyme activities are reported as nmol 4-MUB g ${ }^{-1} \mathrm{~h}^{-1}$.

We used colorimetric assays to determine the activity of phenol oxidase and peroxidase, both of which oxidize phenols and contribute to lignin degradation. A $25 \mathrm{~m} M L$-3,4-dihydroxyphenylalanine ( $L$-DOPA) solution was prepared in acetate buffer to assay the activity of these enzymes. The procedure for measuring the activity of these enzymes was similar to that described above. Clear microplates (LabSystems; Helsinki, Finland) were used for the colorimetric assay, and each contained sixteen replicates of each soil. There were eight blank replicates for each soil (soil with no substrate), as well as eight replicates of a reference standard. For the peroxidase assay, $25 \mu \mathrm{L} \mathrm{H}_{2} \mathrm{O}_{2}$ was added to each well. Following an $18 \mathrm{~h}$ incubation, absorbance was read on an EL-800 plate reader (Biotek Instruments Inc., Winooski, VT) at $450 \mathrm{~nm}$. Activity was reported as $\mu$ mol $L$-DOPA converted per gram per hour. The results of all enzymatic assays are expressed on a dry weight basis. 
Table 2. List of $\mathrm{C}$ sources on BIOLOG GN microplates found in root exudates (Campbell et al., 1997).

\begin{tabular}{lll}
\hline Carbohydrates & Carboxylic acids & \multicolumn{1}{c}{ Amino acids } \\
\hline arabinose & acetic acid & $L$-alanine \\
$D$-fructose & citric acid & $L$-alynyl-glycine \\
$D$-galactose & $\alpha$-keto valeric acid & $L$-asparagine \\
$\alpha$-D-glucose & malonic acid & $L$-aspartic acid \\
maltose & propionic acid & hydroxy $L$-proline \\
$D$-raffinose & succinic acid & $L$-leucine \\
$L$-rhamnose & & $L$-ornithine \\
sucrose & & $L$-phenylalanine \\
& & $L$-serine \\
& & $L$-threonine \\
& & $\gamma$-amino butyric acid \\
\hline
\end{tabular}

\section{Metabolism of Root-Derived Substrates}

We used a subset of BIOLOG GN substrates (BIOLOG, Hayword, CA) that are found as constituents of root exudate to assess their metabolism in rhizosphere soil (sensu Campbell et al., 1997; Table 2). Two 10-g samples of rhizosphere soil were diluted in $100 \mathrm{~mL}$ of a $0.85 \%$ (w/v) $\mathrm{NaCl}$ solution and placed on an electric shaker for $30 \mathrm{~min}$ at $250 \mathrm{rpm}$. Each sample underwent a second dilution; $10 \mathrm{~mL}$ from each sample were placed into $100 \mathrm{~mL}$ of $\mathrm{NaCl}$ solution. We did not adjust our dilutions for differences in inoculum density, because an initial survey indicated that microbial biomass was equivalent across treatments in both rhizosphere and nonrhizosphere soil (D.R. Zak, unpublished data, 1998). From the second dilution, $150 \mu \mathrm{L}$ was used to inoculate individual wells of BIOLOG GN plates, which were subsequently incubated at $25^{\circ} \mathrm{C}$ for $72 \mathrm{~h}$; absorbance at $595 \mathrm{~nm}$ was measured following inoculation and after $72 \mathrm{~h}$ (EL-800; Biotek Instruments, Winooski, VT). At each measurement time, the absorbance value of the control well was subtracted from the absorbance value of all other wells. Using these corrected values, we subtracted the initial absorbance values from those after the 72-h incubation to calculate overall color development, a measure of substrate metabolism.

\section{Statistical Analyses}

Analyses of microbial biomass, microbial respiration, and enzyme activity were performed using a mixed-model ANOVA for a randomized complete block design split by species and time. Block, $\mathrm{CO}_{2}, \mathrm{O}_{3}$, species, and time were fixed effects in this model. To test main effects $\left(\mathrm{CO}_{2}\right.$ and $\left.\mathrm{O}_{3}\right)$, split-plot effects (species), split-split plot effects (time), and their interactions, we derived expected mean squares and used the appropriate mean square for the denominator of each $F$-test. Significance for all statistical analyses was accepted at $\alpha=0.05$.

We used an identical ANOVA model to test for significant differences in the use of root-derived substrates on BIOLOG GN plates. In addition, we conducted a principal components analysis (PCA) to ordinate $\mathrm{CO}_{2}, \mathrm{O}_{3}$, and species treatment combinations by microbial growth on amino acids, organic acids, and simple carbohydrates. Separate PCAs were performed on the corrected absorbance values obtained in May, July, and October.

\section{RESULTS}

\section{Microbial Biomass Carbon and Respiration}

Mean $\mathrm{MB}_{\mathrm{C}}$ in nonrhizopshere soil beneath plants grown under elevated $\mathrm{CO}_{2}\left(90 \mu \mathrm{g} \mathrm{C} \mathrm{g}^{-1}\right)$ was $18 \%$ greater than that beneath plants growing ambient $\mathrm{CO}_{2}\left(76 \mu \mathrm{g} \mathrm{C} \mathrm{g}{ }^{-1}\right.$; main effect means), but this difference was not significant. Mean $\mathrm{MB}_{\mathrm{c}}$ beneath plants grown under elevated
$\mathrm{O}_{3}\left(95 \mu \mathrm{g} \mathrm{C} \mathrm{g}^{-1}\right)$ was greater than the mean value under ambient $\mathrm{O}_{3}\left(70 \mu \mathrm{g} \mathrm{C} \mathrm{g}^{-1}\right.$; main effect means); this difference also was not significant. Microbial respiration did not differ significantly among any treatment or treatment combination (data not shown). However, there were significant differences in both $\mathrm{MB}_{\mathrm{c}}$ and respiration between sampling dates (data not shown), wherein $\mathrm{MB}_{\mathrm{c}}$ and respiration declined over the growing season. Mean $\mathrm{MB}_{\mathrm{c}}$ in May, July, and October were 83, 18, and $15 \mu \mathrm{g}$ $\mathrm{C} \mathrm{g}^{-1}$, respectively. Microbial respiration for May, July, and October averaged 193, 35, and $22 \mu \mathrm{g} \mathrm{CO}_{2}-\mathrm{C} \mathrm{g}^{-1}$ $\mathrm{d}^{-1}$, respectively. We found no significant difference in mean $\mathrm{MB}_{\mathrm{c}}$ or respiration among the aspen, aspen-birch, and aspen-maple species treatments (species main effect).

\section{Enzyme Activities}

The effect of elevated $\mathrm{CO}_{2}$ on phosphatase activity in nonrhizosphere soil varied significantly among species; however, date, $\mathrm{CO}_{2}$, and $\mathrm{O}_{3}$ were not significant as main effects. Phosphatase activity was not influenced by $\mathrm{CO}_{2}$ in nonrhizosphere soil beneath aspen and aspen-birch, but activity was significantly lower beneath aspenmaple (Fig. 1; Table 3).

Leucine aminopeptidase activity did not differ significantly between ambient and elevated $\mathrm{CO}_{2}$ treatments (Fig. 2A). Ozone, time, and species also were not significant as main effects, nor were any interactions significant (Table 3).

In May and October, $\alpha$-glucosidase activity did not differ in the ambient and elevated $\mathrm{CO}_{2}$ treatment. However, activity in July was significantly higher in the elevated $\mathrm{CO}_{2}$ treatment (Fig. 3A). There were no significant effects of time or $\mathrm{O}_{3}$ on $\alpha$-glucosidase activity, nor was there a significant interaction between these factors and species (Table 3 ). Species also was not significant as a main effect.

Time and $\mathrm{CO}_{2}$ interacted to significantly influence $\mathrm{N}$-acetylglucosaminidase (Table 3). On each sampling date, $N$-acetylglucosaminidase activity was significantly greater under elevated $\mathrm{CO}_{2}$, compared with the rate at ambient $\mathrm{CO}_{2}$ (Fig. 3B); this response was disproportionately greater in July. Averaged across sampling date, soils beneath plants grown under elevated $\mathrm{CO}_{2}$ had more rapid rates of $\mathrm{N}$-acetylglucosaminidase activity than the soils under ambient $\mathrm{CO}_{2}$ (Fig. 2C). Ozone and species were not significant as main effects, nor were there any significant interactions (Table 3 ).

On each sampling date, cellobiohydrolase activity was significantly greater under elevated $\mathrm{CO}_{2}$ compared with the rate at ambient $\mathrm{CO}_{2}$ (Table 3; Fig. 3C). Ozone and $\mathrm{CO}_{2}$ also interacted to significantly influence cellobiohydrolase activity. Activity under elevated $\mathrm{CO}_{2}$ and ambient $\mathrm{O}_{3}$ was $43.4 \%$ greater than activity under elevated $\mathrm{CO}_{2}$ and elevated $\mathrm{O}_{3}$ (Fig. 4). Carbon dioxide, $\mathrm{O}_{3}$, and species were not significant as main effects (Table 3 ).

Activities of phenol oxidase and peroxidase did not differ significantly under ambient and elevated $\mathrm{CO}_{2}$ treatments (Figs. 2E, F). Ozone and species also were not significant as main effects, nor was the activity of 


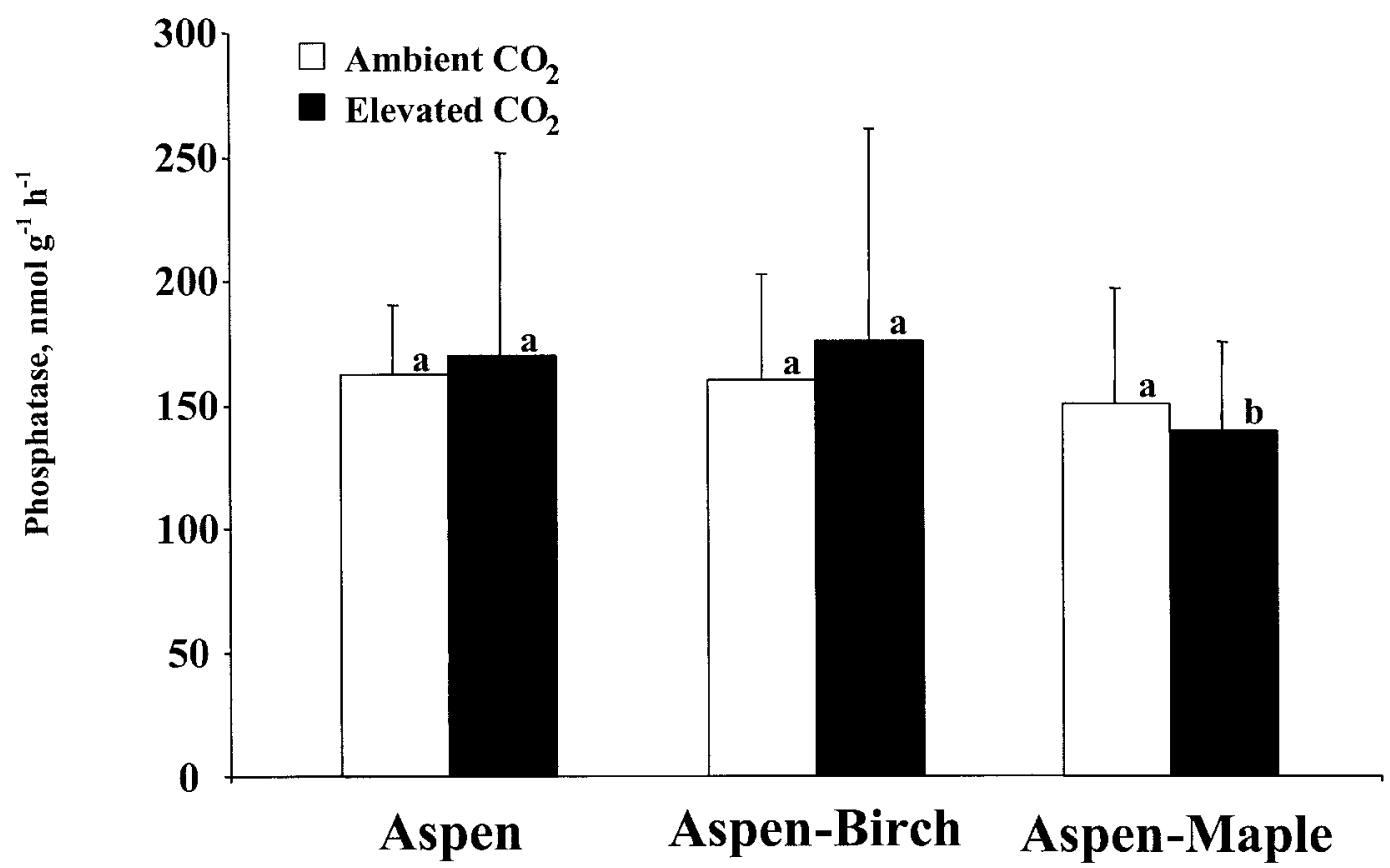

Fig. 1. Mean phosphatase activity in nonrhizosphere soil collected beneath aspen, aspen-birch, and aspen-maple growing under ambient and elevated $\mathrm{CO}_{2}$. Means with the same letter are not significantly different, and one standard deviation is indicated by the length of each error bar.

these soil enzymes influenced by sampling date or the interaction of main factors (Table 3 ).

\section{Metabolism of Root-Derived Substrate}

Metabolism of labile, root-derived substrates in rhizosphere soil (Table 2) was little affected by $\mathrm{CO}_{2}, \mathrm{O}_{3}$, species, and their interactions (data not shown). However, time was a significant main effect in our ANOVA, with greater metabolism of most substrates occurring in July. Nonetheless, we did find that acetic acid, citric acid, and malonic acid were used to a significantly greater extent in May than the other sampling dates. Principal components analysis of the metabolism (color develop- ment) of root-derived substrates on BIOLOG GN plates provided no separation among $\mathrm{CO}_{2}$ and $\mathrm{O}_{3}$ treatments for the aspen and aspen-maple ring sections on all sampling dates. However, in October, PCA of growth on root exudates showed marginal separation along PC 1 for rhizosphere soil collected beneath the aspen-birch species combination grown under elevated $\mathrm{CO}_{2}$ (Fig. 5A). In this analysis, PC 1 accounted for $36 \%$ of the total variance and PC 2 accounted for $20 \%$. The loadings computed for each substrate showed that $L$-serine, $L$-aspartic acid, $L$-asparagine, and $\gamma$-amino-butyric acid weighed most heavily on the positive segment of PC 1 . Citric acid also received a high score on this axis.

Table 3. Analysis of extracellular enzyme activities in nonrhizosphere soil collected beneath contrasting tree species grown under experimental $\mathrm{CO}_{2}$ and $\mathrm{O}_{3}$ treatments. Listed are $P$ values for the significance of each $F$ test in a mixed-model for a randomized complete block design, split by species and time.

\begin{tabular}{|c|c|c|c|c|c|c|c|}
\hline & Phosphatase & $\begin{array}{c}1,4-\alpha- \\
\text { glucosidase }\end{array}$ & $\begin{array}{c}\text { Leucine } \\
\text { aminopeptidase }\end{array}$ & $\begin{array}{c}1,4-\beta-N- \\
\text { acetylglucos- } \\
\text { aminidase }\end{array}$ & Cellobiohydrolase & $\begin{array}{l}\text { Phenol } \\
\text { Oxidase }\end{array}$ & Peroxidase \\
\hline & & & & - $P$ value & & & \\
\hline Block & 0.954 & 0.874 & 0.770 & 0.982 & 0.678 & 0.892 & 0.874 \\
\hline $\mathrm{CO}_{2}$ & 0.662 & 0.280 & 0.554 & 0.019 & 0.068 & 0.898 & 0.606 \\
\hline $\mathbf{O}_{3}$ & 0.394 & 0.771 & 0.355 & 0.109 & 0.065 & 0.243 & 0.631 \\
\hline $\mathrm{CO}_{2} \times \mathrm{O}_{3}$ & 0.916 & 0.320 & 0.611 & 0.213 & 0.043 & 0.720 & 0.686 \\
\hline \multicolumn{8}{|l|}{ Error a: $\operatorname{Block}\left(\mathrm{CO}_{2} \times \mathrm{O}_{3}\right)$} \\
\hline Species & 0.197 & 0.689 & 0.668 & 0.129 & 0.058 & 0.303 & 0.408 \\
\hline Species $\times \mathrm{CO}_{2}$ & 0.017 & 0.234 & 0.190 & 0.231 & 0.242 & 0.757 & 0.466 \\
\hline Species $\times \mathrm{O}_{3}$ & 0.988 & 0.893 & 0.735 & 0.940 & 0.167 & 0.188 & 0.616 \\
\hline Species $\times \mathrm{CO}_{2} \times \mathrm{O}_{3}$ & 0.847 & 0.187 & 0.854 & 0.733 & 0.554 & 0.813 & 0.616 \\
\hline \multicolumn{8}{|l|}{ Error b: Species $\times \operatorname{Block}\left(\mathrm{CO}_{2} \times \mathrm{O}_{3}\right)$} \\
\hline Time & 0.001 & 0.001 & 0.052 & 0.001 & 0.008 & 0.001 & 0.089 \\
\hline Time $\times \mathrm{CO}_{2}$ & 0.124 & 0.035 & 0.511 & 0.028 & 0.050 & 0.537 & 0.647 \\
\hline Time $\times \mathbf{O}_{3}$ & 0.125 & 0.751 & 0.431 & 0.292 & 0.842 & 0.410 & 0.124 \\
\hline Time $\times$ Species & 0.915 & 0.750 & 0.666 & 0.832 & 0.140 & 0.791 & 0.552 \\
\hline Time $\times \mathrm{CO}_{2} \times \mathrm{O}_{3}$ & 0.204 & 0.262 & 0.940 & 0.187 & 0.512 & 0.743 & 0.599 \\
\hline Time $\times$ Species $\times \mathrm{CO}_{2}$ & 0.165 & 0.125 & 0.512 & 0.209 & 0.995 & 0.461 & 0.803 \\
\hline Time $\times$ Species $\times \mathrm{O}_{3}$ & 0.804 & 0.100 & 0.210 & 0.409 & 0.795 & 0.519 & 0.227 \\
\hline Time $\times$ Species $\times \mathrm{CO}_{2} \times \mathrm{O}_{3}$ & 0.473 & 0.074 & 0.269 & 0.030 & 0.803 & 0.551 & 0.863 \\
\hline \multicolumn{8}{|c|}{ Error c: Time $\times$ Species $\times \operatorname{Block}\left(\mathrm{CO}_{2} \times \mathrm{O}_{3}\right)$} \\
\hline
\end{tabular}



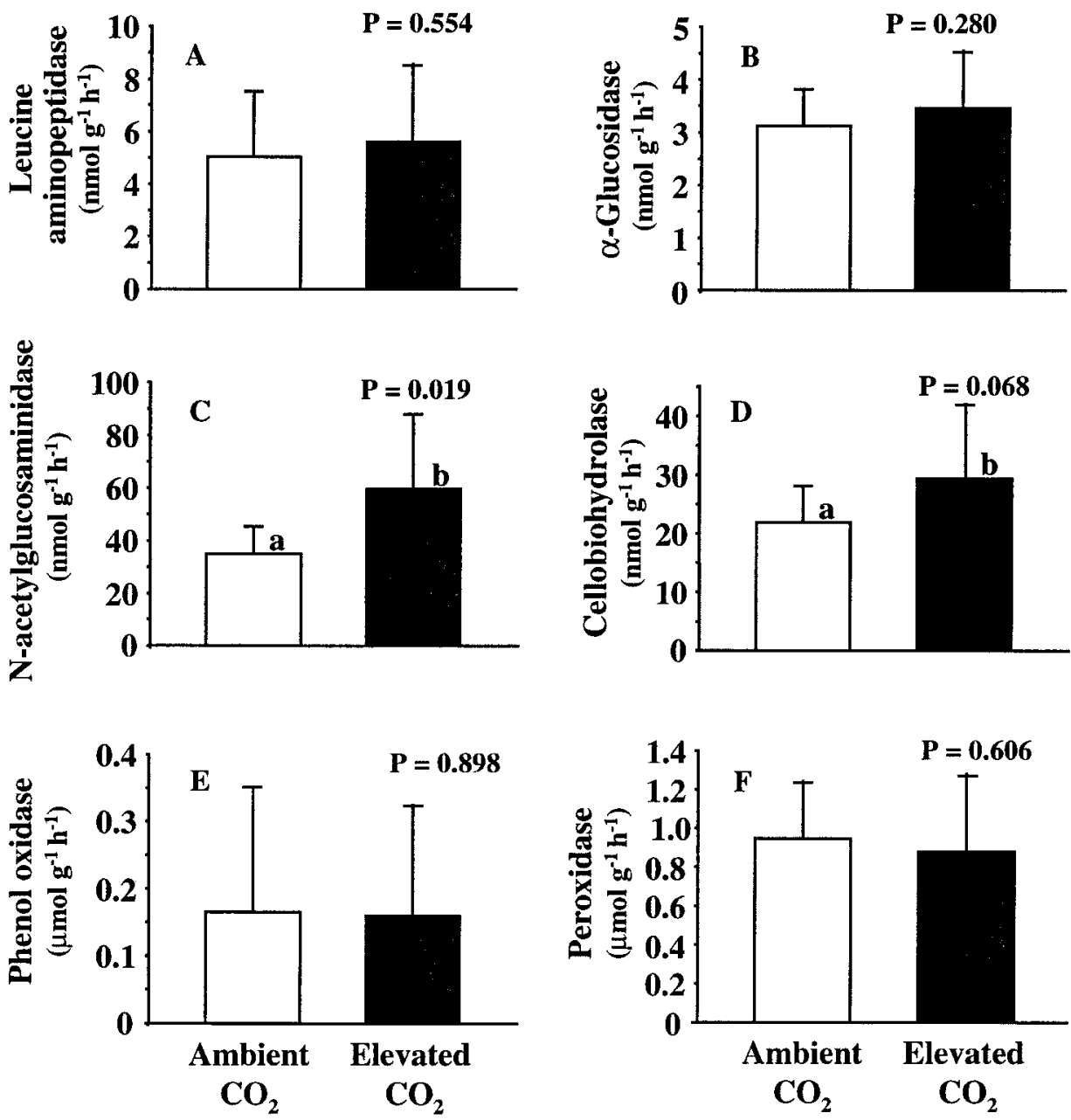

Fig. 2. The mean activity of extracellular enzymes involved in the degradation of plant litter under ambient and elevated $\mathrm{CO}_{2}$. Values are the means in nonrhizosphere soil averaged across ozone, species, and sampling dates. One standard deviation is indicated by the length of each error bar.

When all BIOLOG GN substrates were used, PCA provided virtually no separation among treatments for the aspen and aspen-maple ring sections in May and July. However, in October we did observe marginal separation along PC 1 for aspen-birch grown under elevated $\mathrm{CO}_{2}$ (Fig. 5B). PC 1 accounted for $31 \%$ of the total variance in the model, and PC 2 accounted for $20 \%$. Component loadings computed for each $\mathrm{C}$ source showed that $L$-ornithine, an amino acid found in root exudates and adonitol, a carbohydrate not present in root exudates, received high weights on PC 1. This analysis provided no discrimination of microbial metabolism of root-derived substrates beneath aspen and aspenmaple species combination grown under the $\mathrm{CO}_{2}$ and $\mathrm{O}_{3}$ treatment combinations on the three sampling dates.

\section{DISCUSSION}

Increases in photosynthesis and plant growth, along with altered chemical composition of above and belowground plant tissue, will likely accompany a rise in atmospheric $\mathrm{CO}_{2}$ (Cotrufo et al., 1994; Cotrufo and Ineson, 1995; Kubiske et al., 1997; Curtis et al., 2000; Mikan et al., 2000; Zak et al., 2000a). In our experiment, elevated
$\mathrm{CO}_{2}$ significantly increased the mass of dead fine roots $(>0.5 \mathrm{~mm})$ entering soil and rates of soil respiration; these responses were dampened by the presence of elevated $\mathrm{O}_{3}$ (King et al., 2001). Changes in fine-root litter and soil respiration in response to our experimental treatments were identical to that of cellobiohydrolase activity; it was stimulated by elevated $\mathrm{CO}_{2}$, but elevated $\mathrm{O}_{3}$ diminished this response. We also observed a stimulation of $\mathrm{N}$-acetylglucosaminidase activity under elevated $\mathrm{CO}_{2}$; however, elevated $\mathrm{O}_{3}$ did not significantly influence the activity of this enzyme. Taken together, changes in the input of dead fine roots to soil and changes in the rate of the degradative enzymes suggests that elevated $\mathrm{CO}_{2}$ and $\mathrm{O}_{3}$ have the potential to alter microbial activity by influencing root litter production. Further support for this contention come from the observation that elevated $\mathrm{CO}_{2}$ significantly enhanced the metabolism of ${ }^{13} \mathrm{C}$-labeled cellobiose and $\mathrm{N}$-acetylglucosamine, a response that also was eliminated by elevated $\mathrm{O}_{3}(\mathrm{Phil}-$ lips et al., 2002). Although our sampling occurred after only two growing seasons, changes in belowground plant growth in response to atmospheric $\mathrm{CO}_{2}$ and $\mathrm{O}_{3}$ exerted a detectable influence on microbial activity that was 

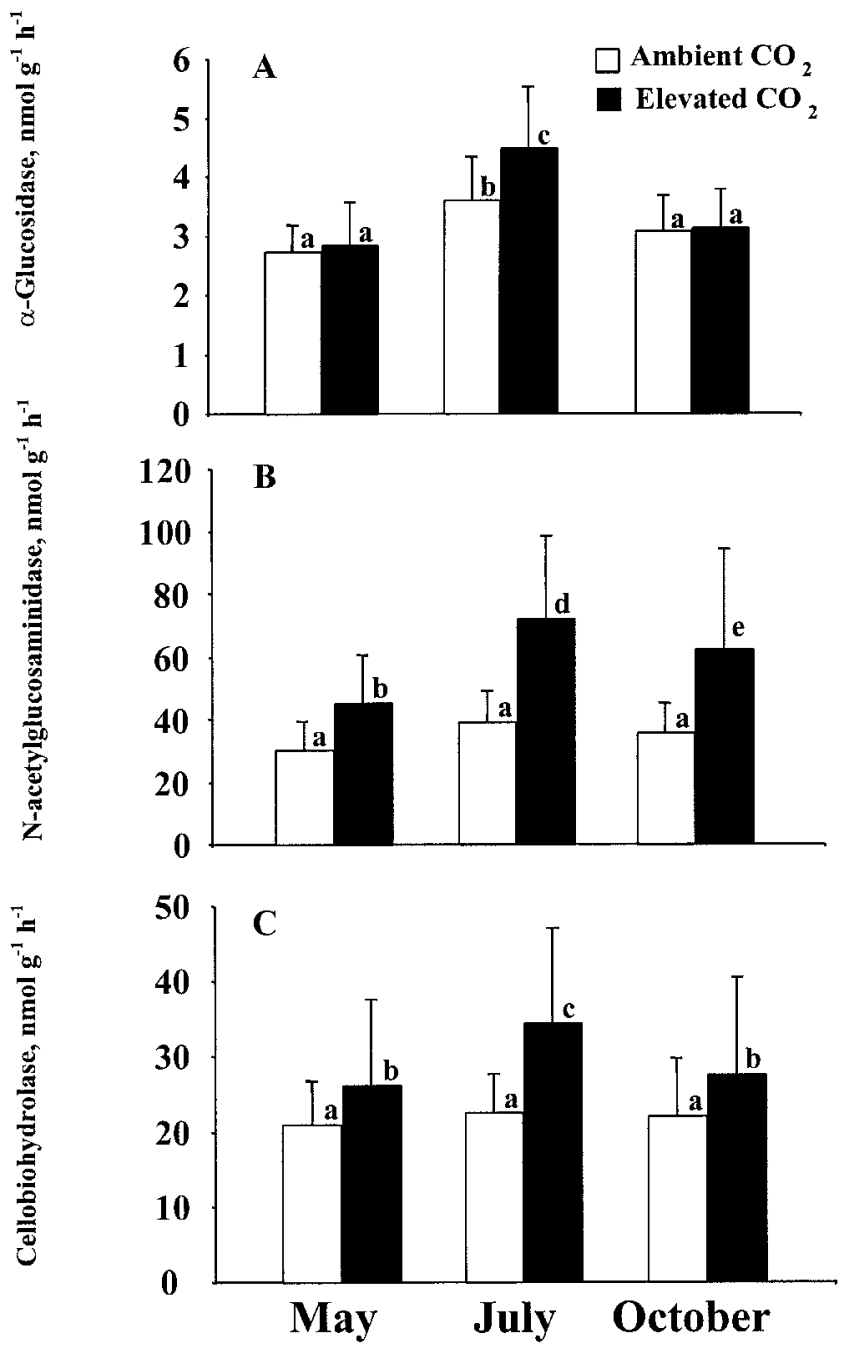

Fig. 3. Mean $\alpha$-glucosidase, $N$-acetylglucosaminidase, and cellobiohydrolase activity in nonrhizospehre soil under ambient and elevated $\mathrm{CO}_{2}$ for May, July, and October sampling dates. Means with the same letter are not significantly different and one standard deviation is indicated by the length of each error bar.

consistent in subsequent growing seasons (Phillips et al., 2002).

Many studies have observed increases in belowground plant productivity under elevated $\mathrm{CO}_{2}$ (Poorter, 1993; Rogers et al., 1994; Curtis and Wang, 1998), a finding which has been hypothesized to foster a larger or more active microbial population in soil (Zak et al., 2000b). However, our results, along with numerous others (Jones et al., 1998; Kampichler et al., 1998; Niklaus, 1998; Hungate et al., 2000), have found no significant response of microbial biomass to elevated $\mathrm{CO}_{2}$. A review of 47 published reports on responses of soil $\mathrm{C}$ and $\mathrm{N}$ cycling to elevated $\mathrm{CO}_{2}$ concluded that microbial biomass can exhibit both large increases and declines beneath woody taxa (i.e., $52 \%$ decline to a $121 \%$ increase), even though microbial respiration generally increases in response to elevated $\mathrm{CO}_{2}$ (Zak et al., 2000b). After $2 \mathrm{yr}$ of $\mathrm{CO}_{2}$ and $\mathrm{O}_{3}$ enrichment of the atmosphere, we were not able to detect a significant response of microbial biomass and respiration to elevated $\mathrm{CO}_{2}$, nor did we find significant species-specific responses to either $\mathrm{CO}_{2}$ or $\mathrm{O}_{3}$. This could be due, in part, to the relatively young age of the plants (i.e., 2 yr old) and the fact that they likely had not fully colonized both aboveand belowground growing space. Several observations made in the subsequent growing season support this idea: elevated $\mathrm{CO}_{2}$ significantly increased fungal activity and the metabolism of ${ }^{13} \mathrm{C}$-cellobiose and ${ }^{13} \mathrm{C}-\mathrm{N}$-acetylglucosamine; moreover, the response of microbial metabolism to $\mathrm{CO}_{2}$ and $\mathrm{O}_{3}$ was greatest beneath aspen and aspen-birch (Phillips et al., 2002). Given the aforementioned results, soil microbial activity appears to be responding in concert with plant growth in our experiment, even though we initially could not detect a significant increase in microbial biomass.

Cellulose comprises up to $40 \%$ of plant tissue (Wilke et al., 1983), and greater root-litter production in response to our experimental treatments should increase cellulose input to soil. In our study, cellobiohydrolase activity increased under elevated $\mathrm{CO}_{2}$, but this increase was only marginally significant $2 \mathrm{yr}$ after initiation of our experimental treatments (Fig. 2D), a response that was consistent in subsequent growing seasons (H. Chung and D.R. Zak, unpublished data, 2001). Concurrent research at our FACE experiment has found a $113 \%$ increase in fine-root biomass for aspen, and an $84 \%$ increase in fine-root biomass in the aspen-birch species combination (King et al., 2001). These results suggest a greater amount of cellulose entered soil under elevated $\mathrm{CO}_{2}$, and this is consistent with the finding that elevated $\mathrm{CO}_{2}$ significantly increased the metabolism of ${ }^{13} \mathrm{C}$-cellobiose by soil fungi in our experiment (Phillips et al., 2002). In combination, increases in root-litter input, greater rates of cellobiohydrolase activity, and more rapid metabolism of labeled cellobiose all indicate that elevated $\mathrm{CO}_{2}$ has enhanced cellulose degradation in soil. In a similar study, Mayr et al. (1999) found a significant increase in cellobiohydrolase activity beneath plants growing under elevated $\mathrm{CO}_{2}$, whereas Dhillion et al. (1996) reported a nonsignificant increase in the activity of this enzyme. These results all suggest an overall increase in cellulose metabolism by microbial communities in nonrhizosphere soil beneath plants exposed to elevated $\mathrm{CO}_{2}$.

In our experiment, greater cellobiohydrolase activity under $\mathrm{CO}_{2}$ was mitigated by elevated $\mathrm{O}_{3}$ (Fig. 4), a response consistent with that of fine-root litter production (King et al., 2001). These observations suggest that changes in root-litter production altered substrate availability and hence the activity of this soil enzyme. The fact that elevated $\mathrm{O}_{3}$ also eliminated enhanced rates of ${ }^{13} \mathrm{C}$-cellobiose metabolism under elevated $\mathrm{CO}_{2}$ further supports this contention (Phillips et al., 2002). We are not aware of other studies that have directly evaluated changes in root-litter production and cellobiohydrolase activity under elevated $\mathrm{O}_{3}$. Nonetheless, ample evidence indicates that elevated $\mathrm{O}_{3}$ can decrease photosynthesis and impair stomatal function (Tjoelker et al., 1995), which can lower the allocation of $\mathrm{C}$ to root growth (Scagel and Andersen, 1997). Moreover, Kress and Skelly (1982) reported a $41 \%$ decrease in biomass of Acer saccharum seedlings, and Wang et al. (1986) reported a 17\% de- 


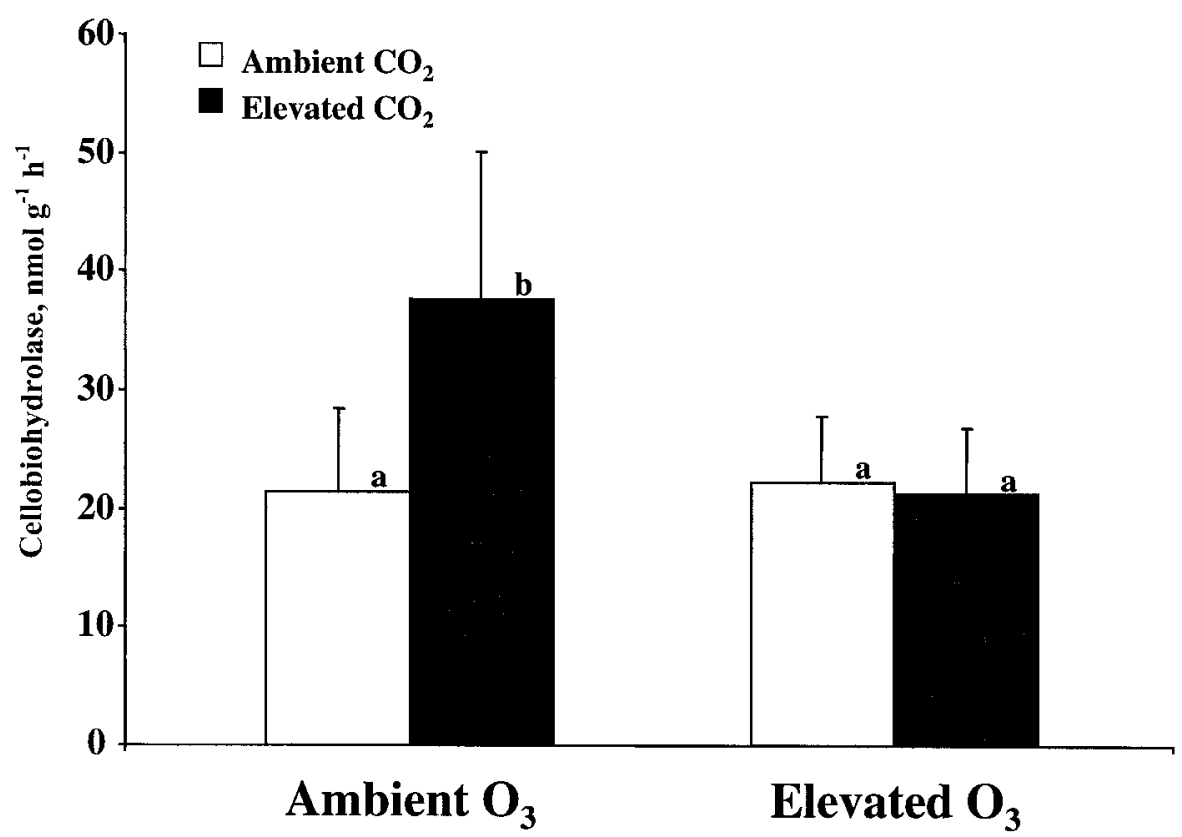

Fig. 4. The interaction of $\mathrm{CO}_{2}$ and $\mathrm{O}_{3}$ on cellobiohydrolase activity in nonrhizosphere soil. Values are means across sampling dates and species treatments, and the standard deviation is indicated by the length of each error bar. Means with the same letter are not significantly different.

crease in biomass of Populus tremuloides seedlings subjected to elevated $\mathrm{O}_{3}$. A decrease in plant growth and allocation to roots under elevated $\mathrm{O}_{3}$ should, in turn, lead to a decline in cellulose input to soil. Such a response
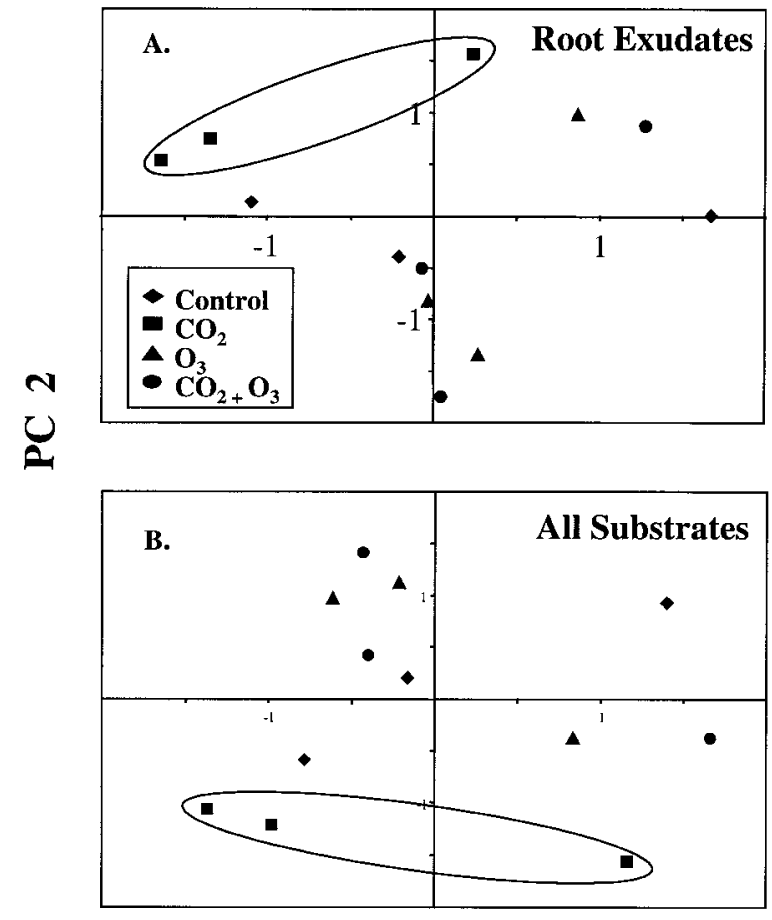

PC 1

Fig. 5. Principal components analysis of microbial growth on BIOLOG GN microplates for (A) root exudates and for (B) all substrates. Results are from rhizosphere soil collected beneath the aspen-birch species combination during the October sampling date, which illustrates the poor discrimination among treatments based on substrate use. would be consistent with our observations of fine-root litter production, cellobiohydrolase activity, and the metabolism of ${ }^{13} \mathrm{C}$-cellobiose (King et al., 2001; Phillips et al., 2002).

$\mathrm{N}$-acetylglucosaminidase is a soil enzyme involved in chitin degradation (Alexander, 1977), and we observed a significant increase in the activity of this enzyme under elevated $\mathrm{CO}_{2}$ (Fig. 2C). Similar results were found in alpine grassland in which $\mathrm{N}$-acetylglucosaminidase activity under elevated $\mathrm{CO}_{2}$ increased by nearly $30 \%$ (Mayr et al., 1999). Although we presently do not have data on specific fungal communities in our experiment, an increase in $\mathrm{N}$-acetylglucosaminidase activity under elevated $\mathrm{CO}_{2}$ may result from a greater production of fungal cell wall litter (Miller et al., 1998). This would be consistent with other studies that have observed greater mycorrhizal infection (\%), and higher levels of mycorrhizal and saprophytic fungal biomass under elevated $\mathrm{CO}_{2}$ (Rillig et al., 1998; Klironomos et al., 1996). $\mathrm{N}$-acetylglucosaminidase in our study displayed a nearly twofold increase with elevated $\mathrm{CO}_{2}$ (Fig. 2C), and the magnitude of this response was similar in the presence and absence of elevated $\mathrm{O}_{3}$ (i.e., no $\mathrm{CO}_{2} \times \mathrm{O}_{3}$ interaction). The relative response of $N$-acetylglucosaminidase to our experimental treatments was similar to that of ${ }^{13} \mathrm{C}-\mathrm{N}$-acetylglucosamine metabolism, which significantly increased under elevated $\mathrm{CO}_{2}$ (Phillips et al., 2002). In combination, these results indicate that chitin degradation was enhanced by elevated $\mathrm{CO}_{2}$, but further work will be required to determine if increases in fungal-litter production are responsible for this observation.

Leucine aminopeptidase is an enzyme involved in the degradation of proteins, and we found no significant difference in the activity of this enzyme under ambient and elevated $\mathrm{CO}_{2}$ (Table 3, Fig. 2A). This result is consistent with Mayr et al. (1999), who found leucine aminopep- 
tidase was unaffected by elevated $\mathrm{CO}_{2}$. We also found no significant influence of $\mathrm{CO}_{2}, \mathrm{O}_{3}$, or species combination on the activity of phenol oxidase, an enzyme involved with lignin degradation (Table 3 ). In the context of our experiment, this implies that protein and lignin inputs from root mortality were unchanged across all treatments. Clearly, chemical analyses of root tissue are needed to support to this contention.

Assaying the metabolism of simple substrates is one approach of assessing physiological capabilities of microbial communities under experimental conditions (Zak et al., 1994). Carbon dioxide, $\mathrm{O}_{3}$, sampling date, and species had no influence on the metabolism of amino acids, organic acids, and simple carbohydrates by microbial communities inhabiting rhizosphere soil. These results are consistent with elevated $\mathrm{CO}_{2}$ studies in Mediterranean (Dhillion et al., 1996) and model tropical ecosystems (Insam et al., 1999), which observed no change in labile substrate metabolism under elevated $\mathrm{CO}_{2}$. In contrast, Mayr et al. (1999) found differences in the metabolic capabilities in an undisturbed, late-successional alpine grassland exposed to elevated $\mathrm{CO}_{2}$. In our experiment, rhizosphere microbial communities equivalently metabolized a range of amino acids, carbohydrates, and organic acids found as constituents of root exudates across all treatments. However, the activity of enzymes involved with plant and fungal cell wall degradation responded significantly to our experimental treatments in nonrhizosphere soil and were consistent with the responses of fine-root litter production.

In summary, we found that greater belowground plant growth under elevated $\mathrm{CO}_{2}$ significantly increased the activities of cellobiohydrolase and $N$-acetylglucosaminidase. In contrast, elevated $\mathrm{O}_{3}$ counteracted the $\mathrm{CO}_{2}$ effect on cellobiohydrolase activity, but elevated $\mathrm{O}_{3}$ had no significant influence on $N$-acetylglucosaminidase activity. Because these enzymes play a key function in the degradation of plant and fungal litter in soil, their response to our experimental treatments may presage a change in decomposition and the flow of substrates through soil food webs. This is consistent with greater rates of ${ }^{13} \mathrm{C}$-cellobiose and $\mathrm{N}$-acetylglucosamine beneath plants growing under elevated $\mathrm{CO}_{2}$ (Phillips et al., 2002). Although the tree taxa we studied broadly differ in lifehistory traits, we have no initial evidence to suggest that changes in belowground growth in response to elevated $\mathrm{CO}_{2}$ and $\mathrm{O}_{3}$ will elicit fundamentally different responses by soil microbial communities (Phillips et al., 2002). Clearly, further work would be required to understand the long-term implication of our observations on the microbial processing of organic matter and its storage in soil. Notwithstanding this caveat, our observations suggest that changes in plant growth induced by high concentrations of $\mathrm{CO}_{2}$ and $\mathrm{O}_{3}$ in the Earth's atmosphere can mediate physiological changes in soil microbial communities, which, in turn, have the potential to alter soil $\mathrm{C}$ and $\mathrm{N}$ cycling in forests. Understanding how changes in plant growth in response to elevated $\mathrm{CO}_{2}$ and $\mathrm{O}_{3}$ impact the long-term dynamics of $\mathrm{C}$ and $\mathrm{N}$ in soil remains an important challenge.

\section{ACKNOWLEDGMENTS}

This manuscript is based on portions of the a thesis submitted by the senior author in partial fulfillment of the Master of Science degree in the School of Natural Resources \& Environment, University of Michigan. Our research was supported by grants from the Department of Energy's Office of Biological and Environmental Research (BER). We sincerely thank David Karnosky, Judd Isebrands, George Hendry, and Kurt Pregitzer, whom devoted numerous hours to the planning and construction of the Rhinelander FACE Experiment.

\section{REFERENCES}

Alexander, M. 1977. Introduction to soil microbiology. 2nd ed. John Wiley and Sons, New York.

Andersen, C.P., W.E. Hogsett, R.Wessling, and M. Plocher. 1991. Ozone decreases spring root growth and root carbohydrate content in ponderosa pine the year following exposure. Can. J. For. Res. 21:1288-1291.

Babiuk, L.A., and E.A. Paul. 1970. The use of fluorescein isothiocyanate in the determination of the bacterial biomass of grassland soil. Can. J. Microbiol. 16:57-62.

Blum, U., and D.T. Tingey. 1977. A study of the potential ways in which ozone could reduce root growth and nodulation of soybean. Atmos. Environ. 11:737-739.

Campbell, C.D., S.J. Grayston, and D.J. Hirst. 1997. Use of rhizosphere carbon sources in sole carbon source tests to discriminate soil microbial communities. J. Microbiol. Methods 30:33-41.

Coleman, M.D., R.E. Dickson, J.G. Isebrands, and D.F. Karnosky. 1995a. Photosynthetic productivity of aspen clones varying in sensitivity to tropospheric ozone. Tree Physiol. 15:585-592.

Coleman, M.D., R.E. Dickson, J.G. Isebrands, and D.F. Karnosky. 1995b. Carbon allocation and partitioning in aspen clones varying in sensitivity to tropospheric ozone. Tree Physiol. 15:593-604.

Cotrufo, M.F., and P. Ineson. 1995. Effects of enhanced atmospheric $\mathrm{CO}_{2}$ and nutrient supply on the quality and subsequent decomposition of fine roots of Betula pendula Roth. and Picea sitchensis (Bong) Carr. Plant Soil 170:267-277.

Cotrufo, M.F., P. Ineson, and A.P. Rowland. 1994. Decomposition of tree leaf litters grown under elevated $\mathrm{CO}_{2}$ : Effect of litter quality. Plant Soil 163:121-130.

Curtis, P.S., and X.Z. Wang. 1998. A meta-analysis of elevated $\mathrm{CO}_{2}$ effects on woody plant mass, form, and physiology. Oecologia 113: 299-313.

Curtis, P.S., C.S. Vogel, X. Wang, K.S. Pregitzer, D.R. Zak, J. Lussenhop, M. Kubiske, and J.A. Teeri. 2000. Gas exchange, leaf nitrogen, and growth efficiency of Populus tremuloides in a $\mathrm{CO}_{2}$ enriched atmosphere. Ecol. Appl. 10:3-17.

Dhillion, S.S., J. Roy, and M. Abrams. 1996. Assessing the impact of elevated $\mathrm{CO}_{2}$ on soil microbial activity in a Mediterranean model ecosystem. Plant Soil 187:333-342.

Dickson, RE., K.F. Lewin, J.G. Isebrands, M.D. Coleman, W.E. Heilman, D.E. Riemenschneider, J. Sober, G.E. Host, D.R. Zak, G.R. Hendry, K.S. Pregitzer, and K.F. Karnosky, 2000. Forest atmosphere carbon transfer and storage (FACTS-II) The aspen freeair $\mathrm{CO}_{2}$ and $\mathrm{O}_{3}$ enrichment (FACE) project: An overview. General Technical Report NC-214. USDA-Forest Service North Central Research Station, St. Paul, MN.

Hogsett, W.E., M. Plocher, V. Wildman, D.T. Tingey, and J.P. Bennett. 1985. Growth response of two varieties of slash pine seedlings to chronic ozone exposures. Can. J. Bot. 63:2369-2376.

Hungate, B.A., C.H. Jaeger III, G. Gamara, S.F. Chapin II, and C.B. Field. 2000. Soil microbiota in two annual grasslands: Responses to elevated atmospheric $\mathrm{CO}_{2}$. Oecologia 124:589-598.

Insam, H., E. Bååth, M. Berreck, Å Frostegård, M.Gerzabek, A. Kraft, F. Schinner, P. Schweiger, and G. Tschuggnall. 1999. Responses of soil microbiota to elevated $\mathrm{CO}_{2}$ in an artificial tropical ecosystem. J. Microbiol. Methods 36:45-54.

Jones, T.H., L.J. Thompson, J.H. Lawton, T.M. Bezemer, R.D. Bardgett, T.M. Blackburn, K.D. Bruce, P.F. Canon, G.S. Hall, S.E Harley, G. Howson, C.G. Hones, C. Kampichler, E. Kandler, and D.A. Richie. 1998. Impacts of rising atmospheric carbon dioxide on model terrestrial ecosystems. Science 280:441-443. 
Kampichler, C., E. Kandeler, R.D. Bardgett, T.H. Jones, and J. Thompson. 1998. Impact of elevated atmospheric $\mathrm{CO}_{2}$ concentration on soil microbial biomass and activity in a complex, weedy field model ecosystem. Global Change Biol. 4:335-346.

King, J.S., K.S. Pregitzer, D.R. Zak, J. Sober, J.G. Isebrands, R.E. Dickson, G.R. Hendry, and D.F. Karnosky. 2001. Fine root biomass and fluxes of carbon in young stands of paper birch and trembling aspen as affected by elevated atmospheric $\mathrm{CO}_{2}$ and tropospheric $\mathrm{O}_{3}$. Oecologia 128:273-250.

Klironomos, J.N., M.C. Rillig, and M.F. Allen. 1996. Below-ground microbial and microfaunal responses to Artemesia tridentata grown under elevated atmospheric $\mathrm{CO}_{2}$. Funct. Ecol. 10:527-534.

Kress, L.W., and J.M. Skelly. 1982. Response of several eastern forest tree species to chronic doses of ozone and nitrogen dioxide. Plant Dis. 66:1149-1152.

Kubiske, M.E., K.S. Pregitzer, C.J. Mikan, D.R. Zak, J.L. Maziasz, and J.A. Teeri. 1997. Populus tremuloides photosynthesis and crown architecture in response to elevated $\mathrm{CO}_{2}$ and soil $\mathrm{N}$ availability. Oecologia 110:328-336.

Lewis, J.D., R.B. Thomas, and B.R. Strain. 1994. Effect of elevated $\mathrm{CO}_{2}$ on mycorrhizal colonization of loblolly pine (Pinus taeda L.) seedlings. Plant Soil 165:81-88.

Manning, W.J., W.A. Feder, P.N. Papia, and I. Perkins. 1971. Influence of foliar ozone injury on root development and root surface fungi of pinto bean plants. Environ. Pollut. 1:305-312.

Mayr, C., M. Miller, and H. Insam. 1999. Elevated $\mathrm{CO}_{2}$ alters community-level physiological profiles and enzyme activities in alpine grasslands. J. Microbiol. Methods 36:35-43.

Mikan, C.J., D.R. Zak, M.E. Kubiske, and K.S. Pregitzer. 2000. Combined effects of atmospheric $\mathrm{CO}_{2}$ and $\mathrm{N}$ availability on the belowground carbon and nitrogen dynamics of aspen mesocosms. Oecologia 124:432-445.

Miller, M., A. Palojärvi, A. Rangger, M. Reeslev, and A. Kjøller. 1998. The use of fluorogenic substrates to measure fungal presence and activity in soil. Appl. Environ. Microbiol. 64:613-617.

Niklaus, P.A. 1998. Effects of elevated atmospheric $\mathrm{CO}_{2}$ on soil microbiota in calcareous grassland. Global Change Biol. 4:451-458.

Paul, E.A., and F.E. Clark. 1996. Soil microbiology and biochemistry. 2nd ed. Academic Press, New York.

Phillips, R.L., D.R. Zak, and W.E. Holmes. 2002. Microbial community composition and function beneath temperate trees exposed to elevated atmospheric $\mathrm{CO}_{2}$ and $\mathrm{O}_{3}$. Oecoloiga 131:236-244.

Poorter, H. 1993. Interspecific variation in the growth response of plants to an elevated ambient $\mathrm{CO}_{2}$ concentration. Vegetatio 104 105:77-97.

Pregitzer. K.S., D.R. Zak, J. Maziasz, J. DeForest, P.S. Curtis, and J. Lussenhop. 2000. Interactive effects of atmospheric $\mathrm{CO}_{2}$ and soil$\mathrm{N}$ availability on fine roots of Populus tremuloides. Ecol. Appl. 10:18-33.
Pye, J.M. 1988. Impact of ozone on the growth and yield of trees: A review. J. Environ. Qual. 17:347-360.

Reich, P.B., D.S. Ellsworth, B.D. Kloeppel, J.H. Fownes, and S.T. Gower. 1990. Vertical variation in canopy structure and $\mathrm{CO}_{2} \mathrm{ex}-$ change of oak-maple forests: Influence of ozone, nitrogen, and other factors on simulated canopy carbon gain. Tree Physiol. 7: 329-345.

Rillig, M.C., M.F. Allen, J.N. Klironomos, N.R. Chiariello, C.B. Field 1998. Plant species-specific changes in root-inhabiting fungi in a California annual grassland: Responses to elevated $\mathrm{CO}_{2}$ and nutrients. Oecologia 113:252-259.

Rogers, H.H., G.B. Runion, and S.V. Krupka. 1994. Plant response to atmospheric $\mathrm{CO}_{2}$ enrichment with emphasis on roots and rhizosphere. Environ. Poll. 83:115-189.

Scagel, C.F., and C.P. Andersen. 1997. Seasonal changes in root and soil respiration of ozone-exposed ponderosa pine (Pinus ponderosa) grown in different substrates. New Phytologist 136:627-643.

Skärby, L., E. Troeng, and C.A. Boström. 1987. Ozone uptake and effects on transpiration, net photosynthesis and dark respiration in Scots pine. Forest Sci. 35:801-808.

Sinsabaugh, R.L., M.J. Klug, H.P. Collins, P. Yeager, and S.O. Petersen. 1999. Characterizing soil microbial communities. p. 476-525. In G.P. Robertson et al. (ed.) Standard soil methods for long term ecological reasearch. Oxford University Press, New York.

Smith, J.L., and E.A. Paul. 1990. The significance of soil microbial biomass estimations. p. 357-393. In J. Bollag and G. Stotsky (ed.) Soil biochemistry. Mercel Dekker, New York.

Tjoelker, M.G., J.C. Volin, J. Oleksyn, and P.B. Reich. 1995. Interaction of ozone pollution and light effects on photosynthesis in a forest canopy experiment. Plant Soil Environ. 18:895-905.

Voroney, R.P., and E.A. Paul. 1984. Determination of kc and $\mathrm{kn}$ in situ for calibration of the chloroform fumigation-incubation method. Soil. Biol. Biochem. 16:9-14.

Wang, D., D.R. Karnosky, and F.H. Bormann. 1986. Effects of ambient ozone on the productivity of Populus tremuloides Michx. grown under field conditions. Can. J. For. Res. 16:47-55.

Wilke, C.R., B. Maiorella, A. Sciamanna, K. Tangnu, D. Wiley, an H. Wong. 1983. Enzymatic hydrolysis of cellulose: Theory and applications. Noyes Data Corporation, New Jersey.

Zak, J.C., M.R. Willig, D.L. Moorhead, and H.G. Wildman. 1994 Functional diversity of microbial communities: A quantitative approach. Soil Biol. Biochem. 26:1101-1108.

Zak, D.R., K.S. Pregitzer, P.S. Curtis, C.S. Vogel, W.E. Holmes, and J. Lussenhop. 2000a. Atmospheric $\mathrm{CO}_{2}$, soil $\mathrm{N}$ availability, and the allocation of biomass and nitrogen in Populus tremuloides. Ecol. Appl. 10:34-46.

Zak, D.R., K.S. Pregitzer, J.S. King, and W.E. Holmes. 2000b. Elevated atmospheric $\mathrm{CO}_{2}$, fine roots and the response of soil microorganisms: A review and hypothesis. New Phytol. 147:201-222. 